\title{
Documentos
}




\section{A contribuição da USP para a Declaração do Rio de Janeiro}

$\mathrm{C}$

onsiderando ser a Terra um sistema que envolve inter-relaçócs complexas entre os componentes da Geosfera c Biosfera, apenas parcialmente compreendidas e suscetíveis de perturbaçáo pelo Homem, o que vem ocorrendo de forma crescente,

Considerando a interdependência entre os ambientes social, econômico e o natural e a necessidade de transição para um modelo de desenvolvimento, o qual seja sustentável, que proporcione equilíbrio perene com o ambiente e contemple a melhoria da qualidade de vida de todos os indivíduos em todos os lugares ao longo do tempo.

\section{Princípios Gerais}

Princípio I - Meio ambiente, desenvolvimento e população

Meio ambiente e desenvolvimento devem ser tratados de forma integrada, tendo o desenvolvimento sustentável a longo prazo precedência sobre os interesses de curto prazo.

Os Estados, organizaçóes e indivíduos deverão assegurar a preservação da diversidade biológica $\mathrm{e}$ as informaçóes genéticas nela contidas em benefício das geraçóes futuras .

Deverá ser preservada a diversidade étnica e cultural dos agrupamentos humanos, em especial dos que mantêm relaçáo sustentável com a Terra.

A solução dos problemas ambientais decorrentes de estado de pobreza deve passar pela erradicaçáo da miséria e da ignorância, a scr alcançada pela ação prioritária de Estados e organizações capazes de prestarem assistência técnica, científica e financeira necessárias.

Princípio 2 - Responsabilidade comum e diferenciada

A fixação de padróes ambientais, respaldados em legislação continuamente atualizada, deve atender ao princípio de que a proteção am- 
biental é responsabilidade comum, porém diferenciada, dos Estados, organizaçóes e indivíduos.

Princípio 3 - Direitos individuais e de grupos

Todo ser humano tem o direito e o dever de viver $\mathrm{cm}$ harmonia com a natureza e em equilíbrio com o meio ambiente, devendo ser assegurada a qualidade do meio ambiente tanto às geraçōes presentes como às futuras.

Princípio 4 - Soberania e responsabilidades com os outros

Os Estados têm o direito soberano de definir e promover seus modelos de desenvolvimento sustentável, ficando estabclecido o dever, para os Estados, organizaçóes e empresas, de evitar o surgimento de danos transfronteiriços, protegendo dessa maneira o ambiente global.

Princípio 5 - Responsabilidade por danos

Nenhum dano ambiental deverá ficar sem punição, e será reparado pelos causadores, devendo estes minimizarem e restaurarem os danos produzidos, arcando com os custos decorrentes, utilizando sempre, entre as tecnologias disponíveis, as mais apropriadas.

Princípio 6 - Princípio da precauçáo

A proteção dos ecossistemas da Terra constitui uma responsabilidade comum da humanidade, cabendo aos Estados, organizaçóes e indivíduos uma atuaçáo compartilhada no que se refere ao seu conhecimento, compreensão, conservaçáo e restauraçáo.

Todos os Estados, organizaçōes e indivíduos deverăo adotar medidas preventivas e impeditivas necessárias para a proteção dos valores ambientais, relativos a quaisquer atividades que possam afetar a Terra, através de prévio levantamento dos riscos ambientais, que devem ser levados ao conhecimento público.

\section{Princípio 7 - A cooperaçáo}

Os Estados, instituiçóes e organizaçóes năo-governamentais deverão cooperar permanentemente, em nível global c regional, de forma a proteger, preservar e recuperar o ambicnte, devcndo os Estados prestar assistência mútua em caso de emergência ou risco ambiental eminente.

A justiça econômica e social para todos os povos da Terra deverá ser buscada através da cooperaçáo global, inclusive pela adoçáo de critérios de desenvolvimento sustentável e pela liberalizaçăo do comércio mundial. 
Principio 8 - Paz e segurança

A solução de controvérsias e litígios internacionais rclativos ao meio ambiente se dará por meios pacíficos.

A paz e a segurança são requisitos essenciais ao desenvolvimento sustentável, devendo os Estados reduzir seus gastos militares e acclerar o desarmamento.

Princípio 9 - Padróes de consumo e produçáo

Todos os Estados, organizações e indivíduos devem comprometerse a mudar seus padróes de consumo, produção c dispêndio de energia que sejam não-sustentáveis, preferindo bens de vida útil mais longa e compatíveis com a preservação ambiental, promovendo preferencialmente o uso de materiais recicláveis.

Principio 10 - Informação e educação

Os Estados e as organizações não-governamentais deverão patrocinar investigaçóes em profundidade para alcançar melhor compreensão. do universo, previsão dos perigos inerentes e estabclecimento dos limites da intervenção humana, promovendo a adequada aplicação desses conhecimentos.

O acesso à educaçáo e à informaçáo deverá ficar assegurado a todos os indivíduos e comunidades, para que possam participar plenamente, por meios democráticos e com conhccimento de causa, na tomada de decisóes que propiciem a transição para o desenvolvimento sustentável e sua manutençáo.

Este texto foi coordenado pelo professor do Instituto de Química da USP, Ivano Gutz, e publicado pela Comissão Coordenadora de Atividades Relacionadas ao Meio Ambiente e Desenvolvimento, presidida pelo vice-reitor da USP Ruy Laurenti, no livro Forrum USP - Meio Ambiente e Desenvolvimento (São Paulo, CCS, maio/92), organizado pelos professores Oswaldo Massambani e Sylvia Suzana Campiglia. 